\title{
Feeding behavior of crossbred steers fed diets containing babassu mesocarp meal and corn in kernels or ground
}

\author{
Aline Evangelista Machado Santana ${ }^{1}$, José Neuman Miranda Neiva ${ }^{2}$, João Restle ${ }^{2}$, Luciano \\ Fernandes Sousa ${ }^{2}$, Fabrícia Rocha Chaves Miotto ${ }^{2}$, Wanderson Martins Alencar ${ }^{1}$, Rafael de \\ Oliveira da Silva1, Vera Lúcia de Araújo²
}

\footnotetext{
${ }^{1}$ Programa de Pós-Graduação em Ciência Animal Tropical, Universidade Federal do Tocantins, Araguaína-TO, Brasil.

2 Escola de Medicina Veterinária e Zootecnia, Universidade Federal do Tocantins, Araguaína-TO, Brasil.
}

\begin{abstract}
The objective of the present study was to evaluate the effect of the use of babassu mesocarp meal (BMM) and corn in different physical forms on the feeding behavior of crossbred young bulls of a dairy breed. Twenty-four crossbred (Nellore vs. Holstein) steers $(307.35 \mathrm{~kg})$ were fed four experimental diets containing two levels of inclusion of the babassu mesocarp meal ( 0 and $412.4 \mathrm{~g} / \mathrm{kg}$ ) and corn in two physical forms (kernels or ground) for 98 days. Data was collected on three days during the finishing phase, with observations every five minutes, for 24 hours. When the activities performed by the animals were evaluated as a function of the period of the day, the physical form of the corn showed interaction with the BMM inclusion level on the time spent feeding and on other activities. When the activities were evaluated over the day, the defecation frequency was affected and decreased as BMM was included. The feeding time was longer at the moments that followed feed supply, whereas the time used for other activities increased during the morning period, regardless of the diet utilized. Rumination and idle times were affected by the period of the day and remained high during the night and morning periods. There was increase in feeding time and dry matter rumination efficiencies and neutral detergent fiber as BMM was added to the diet. The number of rumination chews per bolus, however, decreased as BMB was included. Inclusion of babassu mesocarp meal increases the animal feeding time but the physical form of corn does not change its feeding behavior.
\end{abstract}

Key Words: dry matter rumination efficiency, feeding time, rumination time

\section{Introduction}

Environmental pressures to reduce deforestation in the Amazon areas have stimulated intensification of animal production. This intensification can be shown by animal production in feedlots, which has been characterized by the supply of diets composed of high levels of concentrate and reduced supply of roughage feed. However, changes in the dietary chemical composition may cause alterations in the feeding behavior of animals (Bürger et al., 2000), which may consequently imply variation in animal performance.

Changes in the degree of processing, moisture, feed supply frequency and the type of feed used in the diet formulation can significantly modify the feed intake in the animal and the time it spends on rumination and resting (Van Soest, 1994; Fischer et al., 2002). Thus, an alteration in these activities may result in animals with lower slaughter weight or promote alterations in feed intake, since animals

Received July 02, 2013 and accepted February 13, 2014.

Corresponding author: aline1machado@uft.edu.br

http://dx.doi.org/10.1590/S1516-35982014000500007

Copyright @ 2014 Sociedade Brasileira de Zootecnia. This is an Open Access article distributed under the terms of the Creative Commons Attribution Non-Commercia License, which permits unrestricted non-commercial use, distribution, and reproduction in any medium, provided the original work is properly cited. are capable of increasing the time used for feeding to meet their nutritional requirements when fed low-quality diets (Hodgson, 1990; Costa et al., 2003).

Therefore, the use of babassu mesocarp meal (BMM) may change animal behavior, due to its high NDF contents. However, its particles are too small and are not effective enough to stimulate rumination (Miotto, 2011). Moreover, reduction in the dietary energy value may stimulate dry matter intake by animals, thereby increasing the feeding time. Likewise, processed corn grain can also result in change in animal behavior, given that grinding this feed may reduce rumination time (Van Soest, 1994) and alter the number of daily chews (Owens, 2005).

Therefore, the objective of this study was to evaluate the effect of using babassu mesocarp meal and corn kernels or ground corn on the feeding behavior of feedlot-finished crossbred steers.

\section{Material and Methods}

The experiment was conducted in the experimental area located in Araguaína city, state of Tocantins, Brazil $\left(07^{\circ} 11^{\prime} 28^{\prime \prime}\right.$ South latitude and 48 $12^{\prime} 26^{\prime \prime}$ West longitude), from April to July 2011. During the experimental period, 
meteorological data were collected at the Main Climatology Station of Instituto Nacional de Meteorologia (INMET), of Escola de Medicina Veterinária e Zootecnia, $350 \mathrm{~m}$ away from the experimental area. Average precipitation was $42 \mathrm{~mm}$; maximum and minimum temperatures were 32.77 and $18.7^{\circ} \mathrm{C}$, respectively; average temperature was $25.05^{\circ} \mathrm{C}$; and relative humidity was $76.75 \%$.

The experiment was conducted in a completely randomized design, with treatments distributed into a $2 \times 2$

Table 1 - Chemical composition of the feeds utilized in the experimental diets

\begin{tabular}{lcccc}
\hline g/kg DM & $\begin{array}{c}\text { Pearl millet } \\
\text { silage }\end{array}$ & Corn & $\begin{array}{c}\text { Soybean } \\
\text { meal }\end{array}$ & BMM \\
\hline Dry matter $^{1}$ & 180.5 & 854.1 & 864.2 & 884.2 \\
Crude protein $_{\text {Ether extract }}$ & 70.1 & 60.8 & 446.2 & 34.5 \\
Neutral detergent fiber & 12.7 & 33.9 & 13.3 & 8.1 \\
Acid detergent fiber & 659.5 & 101.1 & 156.9 & 463.7 \\
Hemicellulose & 448.3 & 35.6 & 95.6 & 359.8 \\
Non-fibrous carbohydrates & 211.2 & 65.5 & 61.3 & 103.9 \\
Total carbohydrates & 155.4 & 790.8 & 341.6 & 452.1 \\
Lignin $^{2}$ & 814.9 & 891.9 & 498.5 & 915.8 \\
Ash & 26.5 & 10.5 & 24.5 & 119.5 \\
\hline BMM - basura & 102.3 & 13.4 & 42.0 & 41.6 \\
\hline
\end{tabular}

BMM - babassu mesocarp meal.

${ }^{1} \mathrm{~g} / \mathrm{kg}$ of natural matter

${ }^{2}$ Acid detergent lignin. factorial arrangement (two babassu mesocarp meal levels and two physical forms of corn), using six replications (animals) per treatment. Twenty-four crossbred dairy young bulls, approximately 3 years-old, with $307.75 \mathrm{~kg}$ average weight, were used. The total period in feedlot was 98 days, of which 21 days were used for animals to acclimate to the experimental diets and individual pens, and 77 days were used to feed the animals the evaluated diets and for data collection. During this period, the animals were treated against endo- and ectoparasites and received injectable vitamins A, D and E. Feed was supplied once daily, at $14.00 \mathrm{~h}$, at amounts that would ensure 50 to $100 \mathrm{~g}$ orts $/ \mathrm{kg}$, using pearl millet silage as the roughage feed (Table 1). The diets were formulated according to the NRC (2001), to contain similar protein levels, aiming at a daily weight gain of $1.2 \mathrm{~kg}$ /day (Table 2). The intakes of dry matter (DMI) and neutral detergent fiber (NDF) were measured by weighing the feed supplied and orts collected on the next day. Samples of diets and orts were collected and dried in a forced-ventilation oven, ground in a knife mill with $1 \mathrm{~mm}$ mesh sieves and used to determine the percentages of DM and NDF, according to the methodology described by Silva and Queiroz (2002).

Table 2 - Composition of experimental diets and intakes

\begin{tabular}{|c|c|c|c|c|}
\hline \multirow{2}{*}{ Ingredients in $\mathrm{g} / \mathrm{kg} \mathrm{DM}$} & \multicolumn{2}{|c|}{ Ground corn } & \multicolumn{2}{|c|}{ Corn kernels } \\
\hline & 0 BMM & 412.4 BMM & 0 BMM & $412.4 \mathrm{BMM}$ \\
\hline & \multicolumn{4}{|c|}{ Percentage composition } \\
\hline Pearl millet silage & 72.0 & 72.0 & 72.0 & 72.0 \\
\hline Ground corn & 818.7 & 360.8 & 0.00 & 0.00 \\
\hline Corn grain & 0.00 & 0.00 & 818.7 & 360.8 \\
\hline Soybean meal & 78.3 & 121.8 & 78.3 & 121.8 \\
\hline Babassu mesocarp meal & 0.00 & 412.4 & 0.00 & 412.4 \\
\hline Mineral $^{1}$ & 18.6 & 20.6 & 18.6 & 20.6 \\
\hline \multirow[t]{2}{*}{ Urea } & 12.4 & 12.4 & 12.4 & 12.4 \\
\hline & \multicolumn{4}{|c|}{ Chemical composition } \\
\hline Dry matter ${ }^{2}$ & 790.2 & 787.4 & 788.4 & 798.1 \\
\hline Crude protein & 112.2 & 112.6 & 117.1 & 114.7 \\
\hline Ether extract & 37.8 & 22.3 & 38.6 & 21.9 \\
\hline Neutral detergent fiber & 170.2 & 285.5 & 168.1 & 282.4 \\
\hline Acid detergent fiber & 79.5 & 215.1 & 78.9 & 219.6 \\
\hline Hemicellulose & 90.7 & 70.4 & 89.2 & 62.8 \\
\hline Non-fibrous carbohydrates & 641.4 & 520.8 & 636.7 & 51.96 \\
\hline Total carbohydrates & 811.6 & 806.3 & 804.8 & 802.0 \\
\hline Lignin $^{3}$ & 13.6 & 40.4 & 14.0 & 41.2 \\
\hline Neutral detergent insoluble nitrogen ${ }^{4}$ & 134.4 & 214.9 & 144.7 & 218.7 \\
\hline Acid detergent insoluble nitrogen ${ }^{4}$ & 102.4 & 195.8 & 109.8 & 208.0 \\
\hline \multirow[t]{2}{*}{ Ash } & 38.4 & 58.8 & 39.5 & 61.4 \\
\hline & \multicolumn{4}{|c|}{ Intake } \\
\hline Dry matter, $\mathrm{kg} / \mathrm{day}$ & 8.38 & 13.21 & 8.33 & 9.16 \\
\hline Neutral detergent fiber, $\mathrm{g} / \mathrm{kg}$ LW & 2.70 & 5.80 & 2.30 & 5.10 \\
\hline
\end{tabular}

BMM - babassu mesocarp meal.

${ }^{1}$ Composition: $188.0 \mathrm{~g} / \mathrm{kg}$ calcium; $74.0 \mathrm{~g} / \mathrm{kg}$ sulfur; $24.0 \mathrm{~g} / \mathrm{kg}$ phosphorus; $30.0 \mathrm{~g} / \mathrm{kg}$ magnesium; $60 \mathrm{~g} / \mathrm{kg}$ sodium; $24 \mathrm{mg} / \mathrm{kg}$ cobalt; $240 \mathrm{mg} / \mathrm{kg}$ fluorine; $720 \mathrm{mg} / \mathrm{kg}$ copper; $40 \mathrm{mg} / \mathrm{kg}$ iodine; $1,500 \mathrm{mg} / \mathrm{kg}$ manganese; $8 \mathrm{mg} / \mathrm{kg}$ selenium; $2,080 \mathrm{mg} / \mathrm{kg}$ zinc; $1,830 \mathrm{mg} / \mathrm{kg}$ monensin sodium.

${ }^{2}$ In $\mathrm{g} / \mathrm{kg}$ of natural matter.

${ }^{3}$ Acid detergent lignin.

${ }^{4} \mathrm{In} \mathrm{g} / \mathrm{kg}$ of total nitrogen. 
Behavior was observed on the 27th, 48th and 69th days of the trial, over 24 hours, divided into five periods with different lengths according to the activities performed throughout the day. Feeding, rumination, idling and other activities (licking, scratching, playing) were evaluated every 5 minutes, and the data were analyzed in minutes spent on each activity per day and in minutes per period. The frequencies of drinking, defecation and urination were measured as number of occurrences per day.

The average number of rumination chews per bolus and the time spent chewing per ruminal bolus were recorded in three individual observations performed on three sequential days from $05.00 \mathrm{~h}$ to $08.00 \mathrm{~h}, 17.00 \mathrm{~h}$ to $20.00 \mathrm{~h}$ and $23.00 \mathrm{~h}$ to $02.00 \mathrm{~h}$, using a digital timer (Bürger et al., 2000). The count was taken at every three sequential boli in each observation interval, from the moment the ruminal bolus reached the mouth of the animal until it was swallowed. Based on these variables, the DM feeding efficiency (DM intake/feeding time) (DMFE), given in kilograms of DM consumed per hour $(\mathrm{kg} / \mathrm{h})$; DM rumination efficiency (DM intake/rumination time) (DMRE), given in kilograms of ruminated DM per hour (kg/h); NDF rumination efficiency (NDF intake/ rumination time) (NDFRE), given in kilograms of NDF per hour $(\mathrm{kg} / \mathrm{h})$; chewing time per day (feeding time/day + rumination time/day); and number of chewed boli per day (rumination time per day/chewing time per bolus) were determined according to the methodology proposed by Polli et al. (1996). The number of chews per day, however, was calculated by multiplying the number of rumination chews per bolus by the number of chewed boli per day (Bürger et al., 2000).
The data were subjected to homoscedasticity, normality and sphericity tests, and variance analysis was performed on all quantitative and normal variables, estimated by the methodology of repeated plots in time (PROC MIX, of SAS; Statistical Analysis System, version 8.1) using an unstructured covariance matrix when the activities were evaluated as a function of period of the day. The mathematical model was represented by:

$\gamma \mathrm{ijk}=\mu+\tau \mathrm{i}+\delta \mathrm{j}+\tau \mathrm{i}^{*} \delta \mathrm{j}+a \mathrm{ij}+\beta \mathrm{k}+\beta \mathrm{k}^{*} \tau \mathrm{i}+\beta \mathrm{k}^{*} \delta \mathrm{j}+\beta \mathrm{k}^{*} \tau \mathrm{i}^{*} \delta \mathrm{j}+b \mathrm{k}$, in which: $\gamma \mathrm{ijk}=$ dependent variable; $\mu=$ overall mean; $\tau \mathrm{i}=$ effect of factor i (level of inclusion of the babassu mesocarp meal); $\delta \mathrm{j}=$ effect of factor $\mathrm{j}$ (physical form of corn $) ;\left(\tau \mathrm{i}^{*} \delta \mathrm{j}\right)=$ interaction between factor $\mathrm{i}$ and factor $\mathrm{j} ; a_{\mathrm{ij}}=$ experimental residual error associated with the factorial BMM inclusion level and physical form of corn; $\beta \mathrm{k}=$ effect of factor $\mathrm{k}$ (period of the day); $\beta \mathrm{k}^{*} \tau \mathrm{i}=$ interaction between factor $\mathrm{k}$ and factor $\mathrm{i} ; \beta \mathrm{k}^{*} \delta \mathrm{j}=$ interaction between factor $\mathrm{k}$ and factor $\mathrm{j}$; $\beta \mathrm{k}^{*} \tau \mathrm{i}^{*} \delta \mathrm{j}=$ interaction between $\mathrm{k}$, factor $\mathrm{i}$ and factor $\mathrm{j}$; $b \mathrm{k}=$ experimental residual error associated with period of the day.

When the data were analyzed as a function of the day, the effects associated with the period of the day were removed from the model. The data were subjected to the Tukey test with $\alpha=0.05$ to compare the means when the interaction of the studied factors was not significant $(\alpha>0.05)$.

\section{Results}

The level of BMM inclusion $\times$ corn form interaction had an effect on the defecation frequency, which increased $(\mathrm{P}<0.05)$ in animals fed diets without BMM (Table 3$)$.

Table 3 - Behavior of crossbred young bulls fed the experimental diets

\begin{tabular}{|c|c|c|c|c|c|c|c|c|}
\hline \multirow{2}{*}{ Variables } & \multicolumn{2}{|c|}{ Ground corn } & \multicolumn{2}{|c|}{ Corn kernels } & \multirow{2}{*}{$\mathrm{CV}, \%$} & \multicolumn{3}{|c|}{ P-value } \\
\hline & 0 & 412.4 & 0 & 412.4 & & $\mathrm{BMM}^{1}$ & $\mathrm{Pc}^{2}$ & $\mathrm{BMM} \times \mathrm{Pc}$ \\
\hline $\mathrm{RT}, \mathrm{min} / \mathrm{d}$ & 253.33 & 273.05 & 268.41 & 228.05 & 23.79 & 0.679 & 0.556 & 0.239 \\
\hline $\mathrm{IT}, \mathrm{min} / \mathrm{d}$ & 735.55 & 695.83 & 746.38 & 732.77 & 11.34 & 0.438 & 0.486 & 0.702 \\
\hline $\mathrm{TOA}, \mathrm{min} / \mathrm{d}$ & 275.27 & 247.77 & 239.44 & 233.33 & 18.63 & 0.385 & 0.199 & 0.578 \\
\hline FW & 3.61 & 5.05 & 3.05 & 3.11 & 47.9 & 0.313 & 0.1001 & 0.350 \\
\hline FU & 6.61 & 6.83 & 6.05 & 3.88 & 37.57 & 0.291 & 0.065 & 0.198 \\
\hline CTB, s & 49.89 & 48.52 & 56.24 & 48.39 & 14.21 & 0.134 & 0.305 & 0.285 \\
\hline CTD, h & 7.15 & 8.27 & 7.57 & 7.89 & 22.70 & 0.081 & 0.958 & 0.327 \\
\hline NRCB & 44.28 & 38.65 & 50.65 & 39.92 & 14.90 & 0.006 & 0.160 & 0.350 \\
\hline NCBD & 307.96 & 342.27 & 286.93 & 287.07 & 25.16 & 0.593 & 0.239 & 0.590 \\
\hline $\mathrm{NCD}$ & 13557 & 12952 & 14488 & 11488 & 25.94 & 0.209 & 0.850 & 0.399 \\
\hline DMFE, kg/h & 3.04 & 3.34 & 2.80 & 2.59 & 27.69 & 0.890 & 0.155 & 0.460 \\
\hline DMRE, $\mathrm{kg} / \mathrm{h}$ & 2.09 & 2.72 & 1.99 & 2.79 & 23.20 & 0.005 & 0.950 & 0.715 \\
\hline
\end{tabular}

$\mathrm{CV}$ - coefficient of variation; BMM - babassu mesocarp meal; Pc - processing.

RT - rumination time; FT - feeding time; IT - idling time; TOA - time spent on other activities; FW - frequency of drinking; FD - frequency of defecation; FU - frequency of urination; CTB - chewing time per bolus; CTD - chewing time per day; NRCB - number of rumination chews per bolus; NCBD - number of chewed boli per day; NCD - number of chews per day; DMFE - feeding efficiency of dry matter; DMRE - rumination efficiency of dry matter; NDFRE - rumination efficiency of neutral detergent fiber. 
Among the activities performed by animals throughout the day, only the time spent on feeding showed variation $(\mathrm{P}<0.05)$, in which animals fed diets containing BMM spent more time feeding than those which received diets without it. In spite of the longer period feeding, there was no variation in the time used for rumination, idling or other activities $(\mathrm{P}>0.05)$, and these averaged 255.76, 727.63 and 248.95 minutes per day, respectively. Drinking and urination frequencies also did not show variation according to the experimental diets, averaging 5.31 and 5.95 occurrences per day.

The variables number of rumination chews per bolus $(\mathrm{P}<0.05)$, dry matter rumination efficiency (DMRE) $(\mathrm{P}<0.05)$ and neutral detergent fiber rumination efficiency (NDFRE) $(\mathrm{P}<0.05)$ varied according to the $\mathrm{BMM}$ inclusion level. Although there was no difference in chewing time per bolus, the number of rumination chews per bolus was $17.22 \%$ lower in animals fed BMM, which indicated the lower need for chews on these diets; however, the DMRE and NDFRE expressed in $\mathrm{kg} / \mathrm{h}$ were higher in animals fed BMM than those whose diets did not contain the meal. The chewing time per bolus, chewing time per day, number of chewed boli per day, number of chews per day and dry matter feeding efficiency (DMFE), in turn, did not vary according to the tested factors $(\mathrm{P}>0.05)$, averaging 50.76 s/bolus, $7.72 \mathrm{~h} /$ day, 306.06 boli/d, 1,3121.56 chews/d and $2.94 \mathrm{~kg} \mathrm{DM} / \mathrm{h}$, respectively.

When the behavioral activities were divided over the periods of the day (Table 4), there was interaction between

Table 4 - Behavior of crossbred young bulls fed experimental diets, according to the period of the day

\begin{tabular}{|c|c|c|c|c|c|c|}
\hline \multirow{2}{*}{ Variables } & \multicolumn{2}{|c|}{ Ground corn } & \multicolumn{2}{|c|}{ Corn kernels } & \multirow{2}{*}{ Mean } & \multirow{2}{*}{$\mathrm{CV}, \%$} \\
\hline & 0 & 412.4 & 0 & 412.4 & & \\
\hline \multicolumn{7}{|c|}{ Rumination (minutes) } \\
\hline $14.00-17.55 \mathrm{~h}$ & 25.00 & 30.00 & 33.33 & 22.50 & $27.70 \mathrm{~d}$ & \\
\hline $18.00-23.55 \mathrm{~h}$ & 45.28 & 61.39 & 58.05 & 50.83 & $53.89 \mathrm{~b}$ & \\
\hline $24.00-05.55 \mathrm{~h}$ & 80.27 & 72.77 & 78.05 & 73.88 & $76.24 \mathrm{a}$ & 53.19 \\
\hline $06.00-10.55 \mathrm{~h}$ & 59.72 & 62.50 & 53.89 & 48.88 & $56.25 \mathrm{~b}$ & \\
\hline $11.00-13.55 \mathrm{~h}$ & 43.05 & 46.39 & 45.27 & 31.94 & $41.66 \mathrm{c}$ & \\
\hline \multicolumn{7}{|c|}{ P-value } \\
\hline BMM & $\mathrm{Pc}$ & Period & $\mathrm{BMM} \times \mathrm{Pc}$ & $\mathrm{BMM} \times \mathrm{Pr}$ & $\operatorname{Pc} \times \operatorname{Pr}$ & $\mathrm{BMM} \times \mathrm{Pc} \times \operatorname{Pr}$ \\
\hline 0.6794 & 0.5563 & $<0.0001$ & 0.2391 & 0.7112 & 0.5845 & 0.5072 \\
\hline \multicolumn{7}{|c|}{ Feeding (minutes) } \\
\hline $14.00-17.55 \mathrm{~h}$ & 58.61 & 76.66 & 58.61 & 108.61 & $75.62 \mathrm{a}$ & \\
\hline $18.00-23.55 \mathrm{~h}$ & 53.82 & 65.00 & 60.55 & 70.00 & $62.34 \mathrm{a}$ & \\
\hline $24.00-05.55 \mathrm{~h}$ & 30.55 & 38.61 & 29.44 & 27.77 & $31.59 \mathrm{~b}$ & 39.41 \\
\hline $06.00-10.55 \mathrm{~h}$ & 27.78 & 35.55 & 31.11 & 34.16 & $32.15 b$ & \\
\hline $11.00-13.55 \mathrm{~h}$ & 5.00 & 7.50 & 5.83 & 5.27 & $5.90 \mathrm{c}$ & \\
\hline \multicolumn{7}{|c|}{ P-value } \\
\hline BMM & $\mathrm{Pc}$ & Period & $\mathrm{BMM} \times \mathrm{Pc}$ & $\mathrm{BMM} \times \operatorname{Pr}$ & $\operatorname{Pc} \times \operatorname{Pr}$ & $\mathrm{BMM} \times \mathrm{Pc} \times \mathrm{Pr}$ \\
\hline 0.0018 & 0.2936 & $<0.0001$ & 0.6735 & 0.0017 & 0.1364 & 0.1303 \\
\hline \multicolumn{7}{|c|}{ Idling (minutes) } \\
\hline $14.00-17.55 \mathrm{~h}$ & 73.33 & 80.27 & 87.78 & 66.66 & $77.01 \mathrm{c}$ & \\
\hline $18.00-23.55 \mathrm{~h}$ & 212.50 & 193.05 & 197.78 & 194.44 & $199.44 a$ & \\
\hline $24.00-05.55 \mathrm{~h}$ & 202.77 & 190.55 & 208.33 & 220.01 & $205.41 \mathrm{a}$ & 25.35 \\
\hline $06.00-10.55 \mathrm{~h}$ & 151.66 & 140.28 & 152.22 & 154.44 & $149.65 b$ & \\
\hline $11.00-13.55 \mathrm{~h}$ & 92.27 & 91.66 & 100.27 & 97.22 & $95.35 \mathrm{c}$ & \\
\hline \multicolumn{7}{|c|}{ P-value } \\
\hline BMM & $\mathrm{Pc}$ & Period & $\mathrm{BMM} \times \mathrm{Pc}$ & $\mathrm{BMM} \times \operatorname{Pr}$ & $\operatorname{Pc} \times \operatorname{Pr}$ & $\mathrm{BMM} \times \mathrm{Pc} \times \operatorname{Pr}$ \\
\hline 0.4377 & 0.4863 & $<0.0001$ & 0.7024 & 0.9183 & 0.3774 & 0.2425 \\
\hline \multicolumn{7}{|c|}{ Other activities (minutes) } \\
\hline $14: 00-17: 55 \mathrm{~h}$ & 83.05 & 53.05 & 60.27 & 42.22 & $59.65 \mathrm{a}$ & \\
\hline $18: 00-23: 55 \mathrm{~h}$ & 48.33 & 40.55 & 43.61 & 44.72 & $44.30 \mathrm{~b}$ & \\
\hline $24: 00-05: 55 \mathrm{~h}$ & 46.39 & 58.05 & 44.16 & 38.33 & $46.73 b$ & 41.66 \\
\hline $06: 00-10: 55 \mathrm{~h}$ & 60.83 & 61.66 & 62.77 & 62.50 & $61.94 \mathrm{a}$ & \\
\hline $11: 00-13: 55 \mathrm{~h}$ & 36.66 & 34.44 & 28.61 & 45.55 & $36.31 \mathrm{c}$ & \\
\hline \multicolumn{7}{|c|}{ P-value } \\
\hline BMM & $\mathrm{Pc}$ & Period & $\mathrm{BMM} \times \mathrm{Pc}$ & $\mathrm{BMM} \times \mathrm{Pr}$ & $\operatorname{Pc} \times \operatorname{Pr}$ & $\mathrm{BMM} \times \mathrm{Pc} \times \operatorname{Pr}$ \\
\hline 0.3853 & 0.1993 & $<0.0001$ & 0.5785 & 0.0028 & 0.0896 & 0.2104 \\
\hline
\end{tabular}

Means in the columns followed by different letters differ according to the Tukey test at 0.05 of significance.

$\mathrm{CV}$ - coefficient of variation; BMM - babassu mesocarp meal; Pc - processing; Pr - period. 
the period and the inclusion level of BMM on the variables feeding time $(\mathrm{P}<0.05)$ and other activities $(\mathrm{P}<0.05)$, where animals fed BMM devoted more time to feeding in all periods assessed. The time spent on other activities was longer in the morning period and right after feed supply when animals did not receive BMM. The other variables were only affected by the period of the day $(\mathrm{P}<0.05)$, and only rumination and idle times were increased during the night and early morning and the time used on these activities at times before and after the feed was supplied decreased.

\section{Discussion}

One of the main factors affecting animal performance is voluntary feed intake, which can be affected by massand energy-detection mechanisms, and controlled by nutrient intake, social and environmental conditions and the occurrence of diseases (Forbes, 2003). Thus, the increase in the feeding time as a function of BMM inclusion was possibly a consequence of reduction in the energy content of diets with BMM in relation to those with corn, which resulted in variation in the time the animals spent feeding due to the higher DMI. This variation is a consequence of the animal capacity to increase its intake to meet its nutritional requirements when fed diets of lower qualities, since there is no physical limitation for this.

According to Degasperi et al. (2003), rumination is a reflex performed by the animal trough mechanical stimuli that are related to the type of diet (fiber content) and the quantity ingested and it happens as a way to reduce the size of the feed particle (Fischer et al., 2002; Dias et al., 2011), and also allows greater production and inoculation of bicarbonate in the digesta, which makes it possible to buffer the ruminal environment (Bailey and Balch, 1961; Michael, 1997). According to Sudweeks et al. (1975), reduction of the particle size by grinding reduces the time spent chewing and ruminating, but Beauchemin et al. (1994) stated that the way in which the feed is supplied (restricted or ad libitum) may influence the chewing time during ingestion, and consequently change the total time used for rumination. Therefore, the similar pearl millet content of the experimental diets, coupled with the ad libitum supply of feed to the animals, ensured that the rumination time was similar among the diets, although the corn was provided processed in different forms.

Rumination time is often associated with the NDF content of the diet (Van Soest, 1994; Bürger et al., 2000; Missio et al., 2010), but the results found in the present study demonstrated that increase in the NDF content only was not enough to modify the time spent on this activity, given that the fiber present in BMM is not effective enough to increase the rumination time. In the present study, this was true, because animals fed diets with BMM showed similar rumination time to those whose main dietary energy source was corn. These results agree with those reported by Moya et al. (2010), who observed that the use of byproducts with high percentages of fiber did not result in increase in the time used for rumination and chewing due to their low particle size. Miotto (2011) also did not observe variation in the rumination time of $1 / 2$ Nellore $\times 1 / 2$ Brown Swiss young bulls fed diets containing up to $650 \mathrm{~g} / \mathrm{kg}$ BMM in the total DM; however, the author found average rumination time of 391 minutes, which was higher than the result found herein (255.71), possibly as a function of the higher roughage percentage utilized by the author $(200 \mathrm{~g} / \mathrm{kg} \mathrm{DM})$.

Although the feeding time in animals fed BMM increased, this did not imply alteration in the idle time or other activities, as opposed to the findings of Bürger et al. (2000), who verified that the increase in feeding time resulted in reduction in the time spent idling. These results diverge from those found by Cruz et al. (2012), who observed decreased time on other activities with inclusion of approximately $35 \mathrm{~g} / \mathrm{kg}$ BMM in the diet of Nellore young bulls, and the authors considered this a consequence of the increase in time spent on feeding and rumination for this diet. However, the authors also did not observe change in the idle time, which is an important trait to be considered regarding the studied factors, since decrease in the time used resting increases the energy expenditure by the animal and may lower its performance (Missio et al., 2010).

Although BMM does not have a large enough particle size to stimulate the rumination process, it is possible that the high NDF percentage of this feed contributed to control the ruminal fermentation activity, given that the animals fed BMM showed lower frequency of defecation than those which did not consume the meal. According to Silva (2009), reduction in the neutral detergent fiber intake (NDFI) changes the feces consistency, which becomes less firm than that found with high intake. According to Galyean and Defoor (2003) soft feces are related to the occurrence of disorders such as acidosis, which are common when animals are fed diets with a high percentage of starch due to the abundance of available energetic substrates, and in this case, there was increase in frequency of defecation, which might have occurred in this study when animals consumed diets without BMM.

The chewing time per day can be influenced by the type of feed (moisture and NDF content), particle size, animal age and DM intake, thereby reflecting the characteristics of the diet consumed (Sudweeks et al., 1975; Woodford and 
Murphy, 1988). This variable is a result of the sum of the feeding and rumination times, and it is extremely important to reduce the particle size of the feed, which makes soluble nutrients available for microbial colonization and fermentation (Restle et al., 2009; Dias et al., 2011). In this study, the variation observed in feeding time was not large enough to cause a significant alteration in chewing time per day, which remained constant. The similarity observed in number of chewed boli per day was a consequence of the fact that there were no variations in the rumination time and the time used for chewing each bolus, given that number of chewed boli per day is the result of the division between these variables. Missio et al. (2010) observed increase in number of chewed boli per day as the percentage of non-fibrous carbohydrates in the diet decreased, but this reduction occurred from the increase in the percentage of corn silage that corresponds to a feed capable of stimulating the rumination process due to its particle size, as opposed to that observed with BMM.

According to Missio et al. (2010), the number of rumination chews per bolus is affected by the chemical characteristics of the diet, and this number tends to decrease with reduction in the percentage of effective NDF in the diet. Thus, the results obtained in the present study indicated that the animals fed BMM, in spite of presenting similar chewing time per bolus to those fed diets without it, required a smaller number of chews per bolus to reduce the digesta to a size large enough to pass through the reticulo-omasal orifice. The fact that BMM is formed by small particles possibly resulted in fewer chews required per bolus, since, according to Mertens (1994), for a feed to be able to stimulate rumination, its particle must measure at least $1.18 \mathrm{~mm}$.

The fact that there was no alteration in DMFE indicates that animals fed BMM or corn kernels were as efficient in consuming DM as the others, and they were capable of ingesting a similar amount of DM at each feeding time. These results are in agreement with those found by Miotto (2011), who obtained an average $2.98 \mathrm{~kg} \mathrm{DM}$ for each hour of feeding.

However, the fact that BMM presented a higher percentage of NDF than corn, associated with the higher DMI observed in animals fed diets with the meal, contributed to increase the rumination efficiency of DM and NDF, because the ruminal bolus formed by animals fed BMM showed a higher percentage of NDF, which, coupled with the lower number of chews required per bolus observed with the lower number of rumination chews per bolus in animals fed BMM, contributed to increase the amount of DM and NDF ruminated per hour, thereby elevating these efficiencies, regardless of the physical form of the corn in the diet (ground or kernels). These results corroborate those obtained by Cruz et al. (2012), who included up to $35 \mathrm{~g} / \mathrm{kg}$ BMM in the concentrate fraction of the diet of young Nellore bulls. However, research with diets with different NDF levels as a function of increase in the roughage fraction presents results that disagree with those found herein, because, in those cases, DMRE increased and NDFRE decreased as the NDF supply was reduced (Dulphy et al., 1980; Bürger et al., 2000; Missio et al., 2010). In the present study, the alteration in the percentage of NDF in the diet occurred as a function of the use of a by-product that has a higher NDF content than corn; however, it does not have a particle size capable of reducing DM or the weight of the ruminal bolus.

The animal tends to modify the time used for each activity according to the period of the day; most of the time spent feeding is in the period before the feed is supplied, while idling and rumination usually take place in the fresher periods of the day (Silva, 2009). The results found in the present study agree with those of Silva (2009), who verified increase in the time used on rumination and idle activities during the night period and morning, and reduction in these activities immediately after feed supply, which was the period in which there was increase in the time spent feeding. According to Hübner et al. (2008), this variation in the behavior of the animal over the day is a consequence of the processes of rumen filling and emptying, where the filling caused by feeding triggers the rumination process, which is responsible for the emptying of the rumen (Fischer et al., 2002). The increase observed in the time spent on other activities in the period before feed supply demonstrates that the animals were accustomed to the experimental activities, understanding that the feed would be supplied in that period.

\section{Conclusions}

The use of $412.40 \mathrm{~g} / \mathrm{kg}$ of babassu mesocarp meal in the diet of crossbred young bulls changes their feeding behavior due to their need to increase the feeding time. The supply of corn kernels or ground corn does not modify the behavior of animals fed diets with a high level of concentrate.

\section{Acknowledgments}

Financial support received from $\mathrm{CNPq}$ (National Council for Scientific and Technological Development) in a partnership with Tobasa Indústria e Comércio S. A.

R. Bras. Zootec., 43(5):266-272, 2014 


\section{References}

Bailey, C. B. and Balch, C. C. 1961. Saliva secretion and its relation to feeding in cattle. 2. The composition and rate of secretion of mixed saliva in the cow during rest. British Journal of Nutrition 15:383-402.

Beauchemin, K. A.; McAllister, T. A.; Dong, Y.; Farr, B. I. and Cheng, K. J. 1994. Effects of mastication on digestion of whole cereal grains by cattle. Journal of Animal Science 72:236-246.

Bürger, P. J.; Pereira, J. C.; Queiroz, A. C.; Silva, J. F. C.; Valadares Filho, S. C.; Cecon, P. R. and Casalli, A. D. P. 2000. Comportamento ingestivo em bezerros holandeses alimentados com dietas contendo diferentes níveis de concentrado. Revista Brasileira de Zootecnia 29:236-242.

Costa, C. O.; Fischer, V.; Vetromilla, M. A. M.; Moreno, C. B. and Ferreira, E. X. 2003. Comportamento injestivo de vacas Jersey confinadas durante a fase inicial de lactação. Revista Brasileira de Zootecnia 32:418-424

Cruz, R. S.; Alexandrino, E.; Missio, R. L.; Neiva, J. N. M.; Restle, J.; Melo, J. C.; Sousa Júnior, A. and Resende, J. M. 2012. Feeding behaviors of feedlot bulls fed concentrate levels and babassu mesocarp meal. Revista Brasileira de Zootecnia 41:1727-1738.

Degasperi, S. A. R.; Coimbra, C. H.; Pimpão, C. T.; Souza, F. P.; Darh Chi, K. D.; Glacer Junior, P. and Macedo, R. E. F. 2003. Estudo do comportamento do gado holandês em sistema de semiconfinamento. Revista Acadêmica: Ciências Agrárias e Ambientais $1: 41-47$.

Dias, R. S.; Patino, H. O.; López, S.; Prates, E.; Swanson, K. C. and France, J. 2011. Relationships between chewing behavior, digestibility, and digesta passage kinetics in steers fed oat hay at restricted and ad libitum intakes. Journal of Animal Science 89:1873-1880.

Dulphy, J. P.; Remond, B. and Theriez, M. 1980. Feeding behaviour and related activities in ruminants. p.103-112. In: Digestive physiology and metabolism in ruminants. Ruckebush, Y. and Thivend, P., eds. MTP, Lancaster.

Fischer, V.; Deswysen, A. G.; Dutilleul, P. and Boever, J. 2002. Padrões da distribuição nictemeral do comportamento ingestivo de vacas leiteiras, ao início e ao final da lactação, alimentadas com Dieta à base de silagem de milho. Revista Brasileira de Zootecnia 31:2129-2138.

Forbes, J. M. 2003. The multifactorial nature of food intake control. Journal of Animal Science 81:139-144.

Galyean, M. L. and Defoor, P. J. 2003. Effects of roughage source and level on intake by feedlot cattle. Journal of Animal Science 81:8-16.

Hodgson, J. 1990. Grazing management: science into practice. Longman Handbooks in Agriculture, Longman Scientific \& Techinical, Harlow, Essex, UK.

Hübner, C. H.; Pires, C. C.; Galvani, D. B.; Carvalho, S.; Jochins, F.; Wommer, T. P. and Gasperin, B. G. 2008. Comportamento ingestivo de ovelhas em lactação alimentadas com dietas contendo diferentes níveis de fibra em detergente neutro. Ciência Rural 38:1078-1084.

Mertens, D. R. 1994. Regulation of forage intake. p.450-493. In.: Forage quality, evaluation, and utilization. Fahey, G. C.; Collins, M.; Mertens, D. R. and Moser, L. E., eds. American Society of Agronomy, Crop Science Society of America, and Soil Science Society of America, Madison, WI.

Michael, S. A. 1997. Relationship between fermentation acid production in the rumen and the requirement for physically effective fiber. Journal of Dairy Science 80:1447-1462.

Miotto, F. R. C. 2011. Farelo do mesocarpo do babaçu na produção de bovinos de corte. Tese (D.Sc.). Escola de Veterinária/Universidade Federal de Goiás, Goiânia.

Missio, R. L.; Brondani, I. L.; Alves Filho, D. C.; Silveira, M. F.; Freitas, L. S. and Restle, J. 2010. Comportamento ingestivo de tourinhos terminados em confinamento, alimentados com diferentes níveis de concentrado na dieta. Revista Brasileira de Zootecnia 38:1671-1678.

Moya, D.; Mazzenga, A.; Holtshausen, L.; Cozzi, G.; González, L. A.; Calsamiglia, S.; GIBB, D. G.; McAllister, T. A.; Beaucemin, K. A. and Schwartzkopf-Genswein, K. 2010. Feeding behavior and ruminal acidosis in beef cattle offered a total mixed ration or dietary components separately. Journal of Animal Science 89:520-530.

NRC - National Research Council. 2001. Nutrient requirements of dairy cattle. 7th ed. National Academy Press, Washington, DC.

Owens, F. 2005. Corn grain processing and digestion. Pioneer Hi-Bred International, Johnston, IA.

Polli, V. A.; Restle, J.; Senna, D. B. and Almeida, S. R. S. 1996. Aspectos relativos à ruminação de bovinos e bubalinos em regime de confinamento. Revista Brasileira de Zootecnia 25:987-993.

Restle, J.; Faturi, C.; Pascoal, L. L.; Rosa, J. R. P.; Brondani, I. L. and Alves Filho, D. C. 2009. Processamento do grão de aveia para alimentação de vacas de descarte terminadas em confinamento. Ciências Animal 10:496-503.

Silva, D. J. and Queiroz, A. C. 2002. Análise de alimentos: Métodos químicos e biológicos. 3.ed. Universidade Federal de Viçosa, Viçosa, MG.

Silva, H. L. 2009. Dietas de alta proporção de concentrado para bovinos de corte confinados. 2009. Tese (D.Sc.). Escola de Veterinária/Universidade Federal de Goiás, Goiânia.

Sudweeks, E. M.; McCullough, M. E.; Sisk, L. R. and Law, S. E. 1975. Effects of concentrate type and level and forage type on chewing time of steers. Journal of Animal Science 41:219-224.

Van Soest, P. J. 1994. Nutritional ecology of the ruminant. 2th ed. Cornell University Press, Ithaca.

Woodford, S. T. and Murphy, M. R. 1988. Effect of forage physical form on chewing activity, dry matter intake, and rumen function of dairy cows in early lactation. Journal of Dairy Science 71:674-686. 